\title{
A Study of School Lunch Food Choice and Consumption among Elementary School Students
}

\author{
Ping Hu Johnson*, Deanne Gerson, Kandice Porter and Jane Petrillo \\ Department of Health Promotion and Physical Education, Kennesaw State University, Kennesaw, GA 30144, \\ USA
}

\begin{abstract}
Background: School lunches that are part of the National School Lunch Program must meet specific nutrition requirements. It is unknown whether students eat school lunches in a balanced manner. This study examined which lunch food items children eat/toss, and consumption differences between sexes, and between students at a Non-Title 1 school where most students purchase school lunches and a Title 1 school where most students receive free or reducedpriced lunches.
\end{abstract}

Methods: Students in both schools were observed unobtrusively for five consecutive days. Trained observers recorded the discarded food items on a checklist listing the menu items for the day. The final analyses (t- tests, $z$ tests) included data from 2,826 student-meals.

Results: Entrees similar to those offered in fast food restaurants (i.e., chicken nuggets, pizza, nachos, corndogs) were favored by most students. Fresh fruits and vegetables were not selected or consumed frequently. Boys consumed more food in the fast food, starches, and dessert categories, while girls consumed more soup, salads, and vegetables. Title 1 school students consumed more food in all categories except bread, pasta, and sandwiches than Non-Title 1 school students.

Conclusions: Students' preference of unhealthy lunch items may decrease the health benefits that school lunches attempt to provide.

Keywords: Elementary school student, National School Lunch Program (NSLP), school lunch consumption, food preference, economically disadvantaged student.

The prevalence of obesity has nearly tripled since 1980 in the United States with nearly one-fifth of children ages 6-11 years old being obese (BMI percentile $\geq 95$ th) in 2007-2008 [1] and an additional $17.4 \%$ of children in the same age group being overweight (BMI percentile 85th-<95th) [2]. Physical inactivity and diets that are high in sugar and fats and low in fruits and vegetables have played a key role in the rise of childhood obesity $[3,4]$.

Because most children spend up to eight hours a day, five days a week in school, and eat at least one meal a day at school, many believe that school meals are one factor in the childhood obesity epidemic $[5,6]$. School lunches offering French fries multiple times per week and offering dessert more than once per week each contributed to a significantly higher likelihood of obesity [7]. Children obtain an average of $35 \%$ of their daily energy needs while in school [8] and children who participate in school meals could obtain nearly half of their entire daily energy at school [9]. Since its inception, the National School Lunch Program (NSLP) has provided nutritionally balanced meals to over 30.5 million children each year [10]. When NSLP was

*Address correspondence to this author at the Department of Health Promotion and Physical Education, Kennesaw State University, 590 Cobb Avenue, Building 2, Room 3017, Kennesaw, GA 30144, USA; Tel: 470-578-6216;

Fax: 470-578-9031; E-mail: pjohnso2@kennesaw.edu initially created in 1946, not receiving enough calories was the main concern. Today, the opposite is true [11]. A recent study found a higher overall rate of obesity among students who consume free or reduced-price lunches in all states [12]. The same study also found a lower rate of obesity among students who eat the free or reduced-price lunches in states that mandate school meals exceed the standards set by the United States Department of Agriculture (USDA). To combat childhood obesity, and based on evidence-based recommendations, the USDA issued new standards to increase the number and variety of fruits, vegetables, and whole grains and reduce trans fats and calories in school lunches [13]. While the USDA school meal standards have guided schools in providing children with nutritionally sound meals, little is known whether students actually eat the healthy food choices provided by school meals, and whether there are different school lunch choices between boys and girls and between students at Title 1 school where most students receive free or reduced-fee lunches and those enrolled in a non-Title 1 school where most students purchase lunches and there are more competitive food offerings.Competitive food items are those not offered by the school lunch program and students must purchase them such as ice cream, chips, cookies, crackers, etc. To answer those questions,this study was designed to examine what food options 
elementary school children prefer and whether the healthy foods provided by the school lunch programs are consumed by students. It also assessed whether differences exist in school lunch choices and consumption between students enrolled in a Title 1 and a non-Title 1 schools.

\section{METHODS}

\section{Participants}

An unobtrusive observational study was conducted in a Title 1 and a non-Title 1 elementary school purposefully selected in an urban school district in the Southeastern United States. Participants included kindergarten through fifth grade students who received or purchased lunch in the school cafeteria on the days when data collection took place in both schools in the fall of 2010. The Title 1 school had 995 students with $80 \%$ of them classified as economically disadvantaged and received free or reduced-fee school lunches [14]. The non-Title 1 school enrolled 895 students with $5.49 \%$ of them considered economically disadvantaged, and most of its students purchased their school lunches at the regular price [15].

\section{Instrumentation and Procedure}

A checklist based on the school menus published on each school's website for the days when data collection would take place was developed to record whether and how much a food item was consumed based on a five-point scale with 0 being non-consumed and 4 being fully consumed. During the week of data collection, a salad entrée, a fresh fruit, along with at least one vegetable and one canned fruit side item were offered daily in both schools. Research assistants trained in data collection visited both school cafeterias prior to the data collection. After surveying the layout of the cafeterias and the flow of students during the lunch hours, it was determined that the best location of observation was near the trash cans where students lined up to empty their lunch trays after lunch. A pilot test was conducted to ensure the validity of the data collection checklist and procedure.

Each school was observed on five consecutive days during the entire lunch period. During those days, a good portion of students in both schools brought lunches from home, some only purchased competitive food for lunch, and some were absent. However, it could be certain that students who stood in line to empty their lunch trays were those who purchased or received school lunches. The observers were able to accurately record the type of food on each student's tray based on what they saw on the tray (such as sauce, food debris, leftover food, etc.) as the student waiting for his/her turn to empty his/her lunch tray. Since this is an exploratory observational study, no attempt was made to determine the "response" rate. To observe as many trays as possible, each line of students waiting to empty their lunch trays was observed by two trained observers with each recording alternate trays. The same observers observe the entire lunch period on the day(s) they were observing. The observers took anecdotal notes during the observation as to whether competitive foods were available and whether students purchased them. Data on whether any students purchased competitive foods were not recorded.

\section{Data Analysis}

Data collected were entered into a spreadsheet and analyzed using SPSS. Descriptive statistics were used to determine frequencies and percentages of foods that students selected and consumed. To be consistent with the literature [11], the amout of food consumed was regrouped into little or none consumed (0-1), about half consumed (2), and most or all consumed categories (34). The daily averages of their consumption were obtained and used in data analysis.

To compare food choices and consumption preferences of students between the two schools and between boys and girls, inferential statistics ( $z$ tests and t-tests) were conducted, and the entrée items were grouped into the categories of soups and salad (including tomato soup, chicken tender salad, chef salad, Santa Fe salad, power pack, chicken Caesar salad, taco salad, yogurt and fruit plate, Greek salad, and Asian salad), bread, pasta, and sandwich (grilled cheese sandwich, barbeque pork sandwich, chicken sandwich, pasta, deli sandwich, ravioli, and pancake), fast food (chicken nuggets, corndog, pizza, fish-sticks, hamburger, and nachos), and meat and eggs (meatloaf, baked potato with meat and cheese, omelet, and teriyaki chicken nuggets). For the same reason, side items were grouped into the categories of vegetables (corn, cabbage, okra, broccoli, side green salad, green beans, carrots, coleslaw, spinach, peas and carrots, celery, and cucumber and tomatoes), nonfresh fruit (canned fruit cocktail, peaches, baked peaches, fruit salad, applesauce, pineapple, cinnamon apples, mandarin oranges, and pears), dessert (cinnamon bread, cookie, fruit fiesta, juice bar, and 
baked peaches), starches (rolls, mashed potatoes, breadsticks, macaroni and cheese, rice, pretzels, tater tots, and French fries), and fresh fruits.

\section{RESULTS}

During the five days, a total of 1,532 student meals with $55.3 \%(n=849)$ from males at the Title 1 school were observed, and a total of 1294 student mealswith $50.2 \%,(n=652)$ from males at the non-Title 1 school were recorded. Based on the menus obtained, a total of 16 entrée items and 28 side items (daily average 3.2 and 5.6, respectively) were served at the non-Title 1 school, and 17 entrée items and 35 side items (daily average 3.6 and 7 , respectively) were served at the Title 1 school over the five days of observation. Although nearly half of the entrée items served in both schools were identical, the remaining entrée and side items served in both schools were similar. Several side items including breadsticks, fresh fruits, fruit cocktails, and corn were served on multiple days. Because the number of trained observers varied from two to six on different days, the number of trays observed varied from 198 to 409 in the non-Title 1 school (daily average 258 ) and 231 to 376 in the Title 1 school (daily average 306).

During the five days of the observation, at least three entrée items including a salad entrée and multiple side items that include a fresh fruit and at least one vegetable and one canned fruit were served each day at each school being observed (Table 1). It was also noted that the Title 1 school offered one competitive food item (i.e. ice cream) daily, whereas the non-Title 1 school had multiple competitive food options daily including Rice Krispie treats, ice cream, fruit snacks, Sun Chips, Baked Cheetos, and Doritos. Some children purchased competitive foods for lunch only, while some purchased competitive foods as additions to their meals.

\section{Food Preference by Individual Food Item in the Title 1 School}

Since each entrée food item was served only once durign the data collection period and there were at least three entrée items and multiple side items for students to select per day, the report of food preference by individual food item is based on the proportion of students who selected a particular food item when that food was served on a particular day. The entrée items selected by over half of the students included pizza (90\%), followed by chicken nuggets $(84 \%)$, hamburger $(82 \%)$, omelet $(76 \%)$, and pancakes $(57 \%)$. Over nine of ten students $(93 \%)$ who had chicken nuggets on their trays ate most or all of the nuggets. Similarly, nearly four out of five students who had pizza, omlet, and pancakes on their trays $(78 \%$, $74 \%, 72 \%$, respectively) ate most or all of those foods, and nearly half $(47 \%)$ of those who had hamburgers on their trays ate most or all of the hamburgers. The remaining 11 entrée items that were selected by fewer than one-third of the students included various salads (Greek, Asian, taco, chicken tender, and chicken and

Table 1: Entrée and Side Items Served at the Non-title 1 and Title 1 School

\begin{tabular}{|c|c|c|c|c|}
\hline \multirow{2}{*}{ Day } & \multicolumn{2}{|c|}{ Title 1 School } & Non-title 1 School \\
\cline { 2 - 5 } & Entrée & Side & Entrée & Side \\
\hline \hline 1 & $\begin{array}{c}\text { Nachos, deli sandwich, } \\
\text { Asian salad }\end{array}$ & $\begin{array}{c}\text { Pretzels, corn, celery, pears, } \\
\text { fruit salad, fresh fruit }\end{array}$ & $\begin{array}{c}\text { Tomato soup, grilled cheese } \\
\text { sandwich, chicken nuggets, } \\
\text { chicken tender salad }\end{array}$ & $\begin{array}{c}\text { Roll, corn, cabbage, fruit } \\
\text { cocktail, cinnamon bread, } \\
\text { fresh fruit }\end{array}$ \\
\hline 2 & $\begin{array}{c}\text { Teriyaki chicken, chicken } \\
\text { nuggets, hamburger, taco } \\
\text { salad }\end{array}$ & $\begin{array}{c}\text { Rice, roll, peas and carrots, } \\
\text { French fries, coleslaw, fruit } \\
\text { cocktail, a juice bar, fresh fruit }\end{array}$ & Corndog, meatloaf, chef salad & $\begin{array}{c}\text { Mashed potatoes, okra, } \\
\text { canned peaches, fresh fruit }\end{array}$ \\
\hline 3 & $\begin{array}{c}\text { Baked potato with meat } \\
\text { and cheese, pizza, yogurt } \\
\text { and fruit plate }\end{array}$ & $\begin{array}{c}\text { Spinach, side green salad, } \\
\text { peaches, fruit fiesta, } \\
\text { applesauce, breadstick, fresh } \\
\text { fruit }\end{array}$ & $\begin{array}{c}\text { Pizza, baked potato, Santa Fe } \\
\text { salad }\end{array}$ & $\begin{array}{c}\text { Breadstick, broccoli, side } \\
\text { green salad, fruit salad, } \\
\text { cookie, fresh fruit }\end{array}$ \\
\hline 4 & $\begin{array}{c}\text { Ravioli, omelet, pancakes, } \\
\text { Greek salad }\end{array}$ & $\begin{array}{c}\text { Breadstick, tater tots, side } \\
\text { Caesar salad, carrots, mandarin } \\
\text { oranges, baked peaches, fresh } \\
\text { fruit }\end{array}$ & $\begin{array}{c}\text { Fish sticks, BBQ pork sandwich, } \\
\text { power pack (chicken\& nut } \\
\text { salad) }\end{array}$ & $\begin{array}{c}\text { Mac \& cheese, green beans, } \\
\text { applesauce, coleslaw, fruit } \\
\text { fiesta, fresh fruit }\end{array}$ \\
\hline 5 & $\begin{array}{c}\text { Tomato soup, grilled } \\
\text { cheese sandwich, chicken } \\
\text { nuggets, chicken tender } \\
\text { salad }\end{array}$ & $\begin{array}{c}\text { Roll, corn, cabbage, fruit } \\
\text { cocktail, cinnamon bread, } \\
\text { cucumber and tomato, fresh fruit }\end{array}$ & $\begin{array}{c}\text { Chicken sandwich, pasta, } \\
\text { chicken Caesar salad }\end{array}$ & $\begin{array}{c}\text { Carrots, canned pineapples, } \\
\text { cinnamon apples, breadstick, } \\
\text { corn, fresh fruit }\end{array}$ \\
\end{tabular}


nuts), sandwiches (deli, grilled cheese), baked potato with meat and cheese, pasta, tomato soup, and yogurt and fruit plate. At least one of those entrée items that are mostly the healthier choices were served on each of the days during the study period. Students who did select those items did not eat or ate very little of them.

The top five sides selected by students included French fries $(64 \%)$, mandrin oranges $(49 \%)$, tater tots $(40 \%)$, breadsticks $(39 \%)$, and cinnamon bread $(39 \%)$. With the exception of breadsticks that nearly $70 \%$ of the students who had them on their trays did not eat, over $61 \%$ of the students who had the other four of the top five side items consumed most or all of them. Nearly three-quarters of the students who selected French fries ate most or all of them. Although fresh fruit was selected by $38 \%$ of the students, nearly half of them did not eat the fruit. Similarly, among about 35\% of the students who selected canned mixed fruits, over half $(55 \%)$ ate none or very little of them. All of the vegetable sides were selected by fewer than a third of the students while baked peaches, cucumber and tomato, peaches, coleslaw, cabbage, and peas and carrots being selected by fewer than $10 \%$ of the students. Of the twenty students who selected coleslaw, none ate any or close to half it. Among those who had other healthy choices, such as cabbage, peaches, carrots, celery, side green salad, spinach, and pears on their trays, the majority ate none or little of those sides.

\section{Food Preference by Individual Food Item in the Non-Title 1 School}

Of the 16 entrée items served during the study period, the top five entrée items selected by students included corndogs (68\%), pizza (62\%), chicken sandwichs $(55 \%)$, fishsticks $(35 \%)$, and chicken nuggets $(28 \%)$. About half of the students who had those entrée items on their plates ate most or all of them. Similar to their counterparts in the Title 1 school, very few students selected salad or soup entrées and most ate little or none of those food items.

The top five sides selected by students included macaroni and cheese (62\%), applesauce (54\%), mashed potatos $(41 \%)$, cookies $(41 \%)$, and pineapple $(40 \%)$. While nearly half of the students who had mac and cheese, applesauce, and mashed potatos on their trays ate most or all of them, almost four out of five students who ordered cookies ate most or all of them and nearly half of those who ordered pineapple did not eat any or ate little of it. Similar to the Title 1 school, fewer students selected the healthy side items. Of those side items, about half of the students who had peaches, green beans, and broccoli on their trays ate most or all of them. A majority of students $(>60 \%)$ who ordered fresh fruit and carrots ate none or very little of them. Nearly $45 \%$ of the students who had canned mixed fruits, okra, side green salad, and coleslaw ate none or very little of them. None of the students who ordered cabbage ate it.

\section{Comparison of Food Choice and Consumption by Food Category}

No significant differences regarding the selection of entrée items and side items were found between the boys and girls in both schools except that girls were significantly more likely to have more servings of vegetables than boys (.2951 vs. .2485, $\mathrm{p}=.010$ ) (Table 2).

Table 2: The Comparison of Mean Number of Servings of Sides between Boys and Girls

\begin{tabular}{|c|c|c|c|c|}
\hline & Boys & Girls & $\boldsymbol{t}$ & $\boldsymbol{p}$ \\
\hline \hline Vegetables & .2485 & .2951 & -2.573 & .010 \\
\hline Fruits & .3598 & .3464 & .710 & .479 \\
\hline Desserts & .2132 & .1955 & 1.156 & .248 \\
\hline Starches & .5047 & .5019 & .130 & .896 \\
\hline
\end{tabular}

Table 3 shows that significantly more girls than boys consumed half of the entrée items in the soup and salad category $(70.8 \%$ vs. $29.2 \%, p=.00080)$ and side items in the vegetable category $(55.9 \%$ vs. 44.1 , $\mathrm{p}=.04426$ ). Significantly more boys than girls consumed more than half or all of the entrée items in the fast food category $(57.1 \%$ vs. $42.9 \%, p=.00184)$ and the side items in the desserts and starches categories $(59.8 \%$ vs. $40.2 \%, p=.01137 ; 57.6 \%$ vs. $42.4 \%, p=.01328$; respectively).

As presented in Table 4, significantly more students in the Title 1 school than those in the non-Title 1 school selected an entrée from the fast food category and from the meat and eggs category $(61.2 \%$ vs. 38.8 , $p=.00000 ;$ and $80.7 \%$ vs. $19.3 \%, p=.00000$; respectively); whereas significantly more students in the non-Title 1 school than students in the Title 1 school ordered an entree in the bread, pasta, and sandwich category ( $56 \%$ vs. $43.8 \%, p=.00002)$. In addition, students in the Title 1 school were significantly more likely to select more servings of vegetables, desserts, and starches than students in the 
Table 3: The Comparison of the Consumed Amount of Entrée and Sides between Boys and Girls

\begin{tabular}{|c|c|c|c|c|c|c|c|}
\hline \multirow[t]{2}{*}{ Food Choice } & \multirow[t]{2}{*}{ Amount consumed } & \multicolumn{2}{|c|}{ Boys (N=1501) } & \multicolumn{2}{|c|}{ Girls (N=1325) } & \multirow[t]{2}{*}{ z score } & \multirow[t]{2}{*}{$p$} \\
\hline & & $\mathbf{N}$ & $\%$ & $\mathbf{N}$ & $\%$ & & \\
\hline \multirow[t]{3}{*}{ Soup and Salads } & little or none & 19 & 47.5 & 21 & 52.5 & -.71658 & .47363 \\
\hline & half & 14 & 29.2 & 34 & 70.8 & -3.35329 & .00080 \\
\hline & most or all & 41 & 60.3 & 27 & 39.7 & 1.20103 & .22974 \\
\hline \multirow{3}{*}{$\begin{array}{c}\text { Bread, Pasta, } \\
\text { Sandwiches }\end{array}$} & little or none & 52 & 44.1 & 66 & 55.9 & -2.01159 & .04426 \\
\hline & half & 37 & 56.9 & 28 & 43.1 & .62260 & .53355 \\
\hline & most or all & 107 & 57.5 & 79 & 42.5 & 1.24779 & .21211 \\
\hline \multirow[t]{3}{*}{ Fast Food } & little or none & 89 & 42.8 & 119 & 57.2 & -3.10040 & .00193 \\
\hline & half & 113 & 44.3 & 142 & 55.7 & -2.95238 & .00315 \\
\hline & most or all & 562 & 57.1 & 422 & 42.9 & 3.11429 & .00184 \\
\hline \multirow[t]{3}{*}{ Meat, Eggs } & little or none & 40 & 44.4 & 50 & 55.6 & -1.67501 & .09393 \\
\hline & half & 20 & 58.8 & 14 & 41.2 & .67119 & .50210 \\
\hline & most or all & 151 & 58.1 & 109 & 41.9 & 1.68291 & .09239 \\
\hline \multirow[t]{3}{*}{ Vegetables } & little or none & 187 & 49 & 195 & 51 & -1.75254 & .07970 \\
\hline & half & 52 & 44.1 & 66 & 55.9 & -2.01159 & .04426 \\
\hline & most or all & 110 & 51.2 & 105 & 48.8 & -.59644 & .55088 \\
\hline \multirow[t]{3}{*}{ Non Fresh Fruit } & little or none & 228 & 50.9 & 220 & 49.1 & -1.02697 & .30443 \\
\hline & half & 67 & 53.2 & 59 & 46.8 & .01396 & .98886 \\
\hline & most or all & 227 & 57.3 & 169 & 42.7 & 1.81014 & .07027 \\
\hline \multirow[t]{3}{*}{ Desserts } & little or none & 87 & 50.6 & 85 & 49.4 & -.68680 & .49221 \\
\hline & half & 42 & 49.4 & 43 & 50.6 & -.69450 & .48737 \\
\hline & most or all & 189 & 59.8 & 127 & 40.2 & 2.53101 & .01137 \\
\hline \multirow[t]{3}{*}{ Starches } & little or none & 256 & 49.3 & 263 & 50.7 & -1.91411 & .05561 \\
\hline & half & 108 & 50.9 & 104 & 49.1 & -.65848 & .51023 \\
\hline & most or all & 345 & 57.6 & 254 & 42.4 & 2.47622 & .01328 \\
\hline \multirow[t]{3}{*}{ Fresh Fruit } & little or none & 322 & 55.9 & 254 & 44.1 & 1.53015 & .13280 \\
\hline & half & 65 & 49.2 & 67 & 50.8 & -.91291 & .18064 \\
\hline & most or all & 195 & 52.6 & 176 & 47.4 & -.22913 & .81877 \\
\hline
\end{tabular}

Table 4: The Comparison of Entrée Selections between Students in Non-Title 1 and Students in Title 1 Schools

\begin{tabular}{|c|c|c|c|c|c|c|}
\hline Food Choice & \multicolumn{2}{|c|}{ Title 1 School } & \multicolumn{2}{|c|}{ Non-Title 1 school } & z score & $p$ \\
\hline Soup and Salads & 90 & 57.3 & 67 & 42.7 & -.80584 & .42034 \\
\hline Bread, Pasta, Sandwiches & 162 & 43.8 & 208 & 56.2 & 4.31830 & .00002 \\
\hline Fast Food & 886 & 61.2 & 561 & 38.8 & -7.67191 & $<.000001$ \\
\hline
\end{tabular}

non-Title 1 school (.3290 vs. .2009, $\mathrm{p}=<.0001 ; .0997$ vs. .2937, $\mathrm{p}=<.0001$; and .6332 vs. $.3496, \mathrm{p}=<.0001$; respectively) (Table 5).
Table 6 shows that significantly more students in the Title 1 school consumed most or all of the entrée items in the fast food category and little or none of the 
Table 5: The Comparison of Mean Number of Servings of Sides between Students in Two Schools

\begin{tabular}{|c|c|c|c|c|}
\hline & Title 1 School & Non-Title 1 school & $t$ & $p$ \\
\hline Vegetables & .3290 & .2009 & 7.385 & $<.0001$ \\
\hline Desserts & .2937 & .0997 & -13.433 & $<.0001$ \\
\hline Starches & .6332 & .3496 & -13.984 & $<.0001$ \\
\hline
\end{tabular}

Table 6: The Comparison of the Consumed Amount of Entrée and Sides between the Two Schools

\begin{tabular}{|c|c|c|c|c|c|c|c|}
\hline \multirow[t]{2}{*}{ Food Choice } & \multirow[t]{2}{*}{ Amount consumed } & \multicolumn{2}{|c|}{ Title 1 School } & \multicolumn{2}{|c|}{ Non-Title 1 School } & \multirow[t]{2}{*}{ z score } & \multirow[t]{2}{*}{$p$} \\
\hline & & $\mathbf{N}$ & $\%$ & $\mathbf{N}$ & $\%$ & & \\
\hline \multirow{3}{*}{$\begin{array}{l}\text { Soup and } \\
\text { Salads }\end{array}$} & little or none & 24 & 60 & 16 & 40 & -.74014 & .45922 \\
\hline & half & 27 & 56.3 & 21 & 43.8 & -.28599 & .77488 \\
\hline & most or all & 38 & 55.9 & 30 & 44.1 & -.28004 & .77945 \\
\hline \multirow{3}{*}{$\begin{array}{c}\text { Bread, Pasta, } \\
\text { Sandwich }\end{array}$} & little or none & 60 & 50.8 & 58 & 49.2 & .74914 & .45377 \\
\hline & half & 22 & 33.8 & 43 & 66.2 & 3.33399 & .00086 \\
\hline & most or all & 79 & 42.5 & 107 & 57.5 & 3.32432 & .00089 \\
\hline \multirow[t]{3}{*}{ Fast Food } & little or none & 117 & 56.3 & 91 & 43.8 & -.61326 & .53970 \\
\hline & half & 112 & 43.9 & 143 & 56.1 & 3.45755 & .00055 \\
\hline & most or all & 657 & 66.8 & 327 & 33.2 & -9.79296 & $<.00001$ \\
\hline \multirow[t]{3}{*}{ Meat, Eggs } & little or none & 67 & 74.4 & 23 & 25.6 & -3.91559 & .00009 \\
\hline & half & 23 & 67.6 & 11 & 32.4 & -1.58204 & .11364 \\
\hline & most or all & 220 & 84.6 & 40 & 15.4 & -10.3266 & $<.00001$ \\
\hline \multirow[t]{3}{*}{ Vegetables } & little or none & 240 & 62.8 & 142 & 37.2 & -3.63427 & .00028 \\
\hline & half & 78 & 66.1 & 40 & 33.9 & -2.64844 & .00809 \\
\hline & most or all & 148 & 68.8 & 67 & 31.2 & -4.47829 & .00001 \\
\hline \multirow[t]{3}{*}{ Non Fresh Fruit } & little or none & 254 & 56.7 & 194 & 43.3 & -1.15110 & .24969 \\
\hline & half & 51 & 40.5 & 75 & 59.5 & 3.16581 & .00155 \\
\hline & most or all & 224 & 56.6 & 172 & 43.4 & -1.01427 & .31046 \\
\hline \multirow[t]{3}{*}{ Desserts } & little or none & 152 & 88.4 & 20 & 11.6 & -9.27916 & $<.00001$ \\
\hline & half & 57 & 67.1 & 28 & 32.9 & -2.41407 & .01578 \\
\hline & most or all & 236 & 74.7 & 80 & 25.3 & -7.75073 & $<.00001$ \\
\hline \multirow[t]{3}{*}{ Starches } & little or none & 331 & 63.8 & 188 & 36.2 & -4.84098 & $<.00001$ \\
\hline & half & 126 & 59.4 & 86 & 40.6 & -1.58709 & .11249 \\
\hline & most or all & 425 & 71 & 174 & 29 & -9.23678 & $<.00001$ \\
\hline \multirow[t]{3}{*}{ Fresh Fruit } & little or none & 288 & 50 & 288 & 50 & 2.27330 & .02301 \\
\hline & half & 64 & 48.5 & 68 & 51.5 & 1.35240 & .17625 \\
\hline & most or all & 248 & 66.8 & 123 & 33.2 & -5.24100 & $<.00001$ \\
\hline
\end{tabular}

entrée items in the bread, pasta, and sandwich group than their counterparts in the non-Title 1 school $(66.8 \%$ vs. $33.2, p=.00000 ; 42.5 \%$ vs. $57.5 \%, p=.00089$; respectively). For side items, significantly more students in the Title 1 School than students in the nonTitle 1 school ate more than half or all of the items in the vegetables, desserts, starches, and fresh fruit groups $(68.8 \%$ vs. $31.2 \%, p=.00001 ; 74.7 \%$ vs. $25.3 \%$, 
$\mathrm{p}=.00000 ; 71 \%$ vs. $29 \%, \mathrm{p}=.00000 ;$ and $66.8 \%$ vs. $33.2 \%, p=.00000$; respectively). Also, significantly more students in the non-Title 1 school than those in the Title 1 school ate half of the side items in the nonfresh fruit group $(59.5 \%$ vs. $40.5, p=.00155)$.

\section{DISCUSSION}

This study found that the healthier entrée choices were selected by a small percentage of the students (between $2 \%$ and $33 \%$ ), as compared to the unhealthy entrée items selected by a majority (60-90\%) of the students in both schools. Noteworthy is the large proportion of the students, especially those in the Title 1 school, that consumed most or all of the unhealthy portion of the meals such as the fast food items, and threw away the healthy items that made the meals nutritionally balanced. The popular entrée items, selected and consumed mostly or all by more students in both schools, appeared to be less healthy including pizza, chicken nuggets, corndogs, fish-sticks, and hamburgers. The not-so-popular entrée items seemed to be those in the categories of soups and salad; bread, pasta, and sandwiches; and meat and eggs. The popular side items were those in the dessert and starches categories such as cookies, French fries, macaroni and cheese, mashed potatoes, and tater tots. The less popular sides were the healthy options such as vegetables, fresh fruits, and non-fresh fruits. Those findings are consistent with previous studies $[11,16]$ that although school lunches that are part of the NSLP program meet nutritional standards, the actual average lunch children received and consumed did not meet nutritional standards.

Such phenomena could be explained by the fact that children are more likely to choose foods based on their taste [11], parental influences [17], previous food experience [18], and influence of food marketing that link less-nutritious foods to toys and popular cartoon and movie characters [18, 19]. Although previous research [11] found that over $60 \%$ of the elementary school children had a fruit on their lunch tray and at least $80 \%$ of those who had a fruit on their lunch tray ate the fruit, the present study only found about one third of the students had a fruit serving on their lunch tray. As high as $62 \%$ of the students in the non-Title 1 and $55 \%$ of those in the Title 1 schools did not eat or only ate little of the fruit on their tray. Contrary to the finding that children are more likely to eat more fruits and vegetables when they have easy access to those foods [20], a majority of the students observed in this study did not select a salad entrée, a fruit, or a vegetable side that were served daily. For the small number of students who did select one or more of those healthy choices, they threw away most, if not all, of them.

The differences in preference of food choices between boys and girls observed in this study are consistent with previous research [21] that girls enjoyed vegetables more, and boys preferred meat, fish, and poultry items. During the five days of observation, the Title 1 school served significantly more sides than the non-Title 1 school. It is possibly due to the fact that a majority of the Title 1 school students received free or reduced-fee lunches must have at least two side items.

As compared to their counterparts in the non-Title 1 school, students in the Title 1 school were more likely to have entrée items in the fast food, and meat and eggs categories and more servings of vegetables, desserts, and starches on their trays. In addition, they also were more likely to consume most or all of their lunch items including fruits and vegetables on their trays. This finding is consistent with a previous study [22] that students from low-income families consumed more lunch items in all food groups. Such differences in food choices and consumptions among students could be due to the possibility that individual food preference is influenced by past experience of the foods and parental influence $[17,18]$. They could also be related to the difference in socioeconomic status of students in the two schools with significantly more students in the Title 1 school being classified as economically disadvantaged and most of the students in the nonTitle 1 school were from families with higher socioeconomic statuses $[14,15]$. It is known that healthy foods such as fruits and vegetables are less accessible to low-income families [23], and many low income families have very low food security [24]. As compared to middle income families, low income families are almost twice as likely to reduce or miss meals or have limited income to pay for food [25]. As a result, students from low income families may be less likely to have been exposed to healthy food choices and may not have enough food at home. On the other hand, students from higher social economic statuses are more likely to have been exposed to healthy food choices and less likely to be concerned with not having food available at home [26].

Students at the Title 1 school could purchase one competitive food, whereas students at the non-Title 1 school could purchase and consume multiple competitive food offerings. Again the economic 
statuses of families could explain why the non-Title 1 school offered more competitive food options than the Title 1 School did. Those findings are consistent with the report by Wharton, Long, and Schwartz [27] that the introduction of competitive foods has been shown to significantly reduce the amount of fruit and vegetables that children consume, and, students who received a free or reduced-price lunch, were more likely to consume fruits and vegetables and less likely to consume competitive foods.

\section{LIMITATIONS}

As an exploratory study, only one Title 1 School and one non-Title 1 school were observed. Results of this study may not be typical of all Title 1 or non-Title 1 schools. Therefore, the generalization of the findings from this study must be made with caution. Because the content on each lunch tray was observed and recorded by one observer, it is possible that some trained observers might have mismarked certain food items or consumption amount, which might have had certain impact on the accuracy of the results. To increase the accuracy of data in future studies, each tray should be observed by two trained observers. Because the number of lunch trays observed varied on different days, results from this study are intended to provide a general overview of student lunch item preferences and consumption. Lastly, the lunch items served in the two schools were not identical, making the comparison of students' food selections and consumptions not as accurate. Future studies should work with the schools to set and serve exactly the same menu items on the same days of the observation.

\section{CONCLUSIONS}

Although both schools examined in this study provide balanced meal options for their students, the actual lunches most students in both schools consumed included mostly food items commonly served in fast food restaurants, with few or none of the healthier food options. Girls and boys had different food preferences with girls liking vegetables more, and boys enjoying meat, fish, and poultry items more. The school lunch seemed to be a main meal for the day for students from disadvantaged families, and more competitive food choices were offered in the non-Title 1 school than that offered in the Title 1 school. It is clear that students' food choices, their actual consumption of different foods, and the influence of competitive foods, may decrease the health benefits that school meals attempt to provide.

\section{IMPLICATIONS}

The results from this study strongly suggest that schools should develop effective nutrition education programs that not only provide general nutrition knowledge, but also influence children's food preferences and empower students to make wise nutrition decisions. Although stricter school lunch standards have improved weight status among school lunch participants [12], it is more important to help students, especially those who purchase school lunches, to develop the ability to select and eat healthy food offerings voluntarily. Because school aged children consume at least half of their meals outside of schools on average and will make food choices when they become adults, it is critical that they are able to make healthy dietary choices.

As parental influences have a major impact on student food choices [17], school nutrition programs should target the parents, especially those from disadvantaged families. Schools should involve Parent Teacher Association and work with local community, businesses, and grocery stores to offer nutrition classes, healthy meal planners and recipes, cooking demonstrations, and hands-on cooking practices. Because students' food preference is influenced in part by their past experiences of the foods [18], school nutrition programs should provide food tasting opportunities to expose students to the healthy food items that they may not have had at home or in the past. As students are more likely to have had experience with locally grown foods, schools should serve those foods as much as possible.

Since schools cannot compete with commercial marketing of less-healthy foods [17, 18], they can develop and implement fun and educational activities for their students and parents. For example, the school districts could organize monthly healthy food recipe contests and invite students and parents to vote for the winners. The winning recipes would be included in the following month's school lunch menu, and posted on district websites for parents to use.

In an attempt to reduce food waste, the USDA issued Updated Offer versus Serve Guidelines for the NSLP and School Breakfast Program in School Year 2013-2014 [28]. School district nutrition services should design school lunch menus that meet not only the USDA requirements, but the food preferences of children to increase the chance that the lunches students actually consume are nutritionally balanced 
and less food is wasted. Schools can invite students with different demographic characteristics and backgrounds each week to taste a selection of healthy food items from the menu and provide feedback on how those foods should be modified to meet their preference. Those students would be more likely to select and eat the modified offerings based on their feedback and it may also influence their peers to select and eat those foods. Lastly, schools should evaluate competitive foods offerings and determine if changes should be made to promote healthier dietary choices among students.

\section{HUMAN SUBJECT APPROVAL STATEMENT}

This study was approved by the Kennesaw State University's institution review board and Cobb County School District Office of Accountability.

\section{REFERENCES}

[1] NCHS Health E-Stat [monograph on the internet]. Prevalence of obesity among children and adolescents: United States, trends 1963-1965 through 2007-2008 [Updated 2010 June 4; cited 2013 August 29]: Available from: http://www.cdc.gov/nchs/data/hestat/obesity_child_07_ 08/obesity_child_07_08.htm\#table1

[2] Moreno G, Johnson-Shelton D, Boles S. Prevalence and prediction of overweight and obesity among elementary school students. J Sch Health 2013; 83: 157-63.

http://dx.doi.org/10.1111/josh.12011

[3] Hovland J, Mcleod S, Duffrin M, Johanson G, Berryman D. School-based screening of the dietary intakes of third graders in rural Appalachian Ohio. J Sch Health 2010; 80: 536-43.

http://dx.doi.org/10.1111/j.1746-1561.2010.00539.x

[4] O'brien L, Polacsek M, MacDonald P, Ellis J, Berry S, Martin M. Impact of a school health coordinator intervention on health-related school policies and student behavior. J Sch Health 2010; 80: 176-85. http://dx.doi.org/10.1111/j.1746-1561.2009.00484.x

[5] Baxter S, Hardin J, Guinn C, Royer J, Mackelprang A, Devlin C. Children's body mass index, participation in school meals, and observed energy intake at school meals. Int J Behav Nutr Phys Act 2010; 7: 1-8. http://dx.doi.org/10.1186/1479-5868-7-24

[6] Nestle M. School meals: A starting point for countering childhood obesity. JAMA Pediatr 2013; 167: 584-5. http://dx.doi.org/10.1001/jamapediatrics.2013.404

[7] Fox MK, Dodd AH, Wilson A, Gleason PM. Association between school food environment and practices and box mass index of US public school children. J Am Diet Assoc 2009; 109: S108-17.

[8] Briefel RR, Wilson A, Gleason PM. Consumption of lownutrient, energy-dense foods and beverages at school, home, and other locations among school lunch participants and nonparticipants. J Am Diet Assoc 2009; 109: S79-90.

[9] Briefel RR, Crepinsek MK, Cabili C, Wilson A, Gleason PM. School food environments and practices affect dietary behaviors of US public school children. J Am Diet Assoc 2009; 109: 91-107.

http://dx.doi.org/10.1016/j.jada.2008.10.059
[10] USDA [homepage on the Internet]. National School Lunch Program, 2009 [Updated 2010 June 8; cited 2010 June 8]: Available from: http://www.fns.usda.gov/cnd/lunch/ AboutLunch/NSLPFactSheet.pdf

[11] Schwartz M. The influence of a verbal prompt on school lunch fruit consumption: A pilot study. Int $\mathrm{J}$ Behav Nutr Phys Act 2007; 4: 1-5.

http://dx.doi.org/10.1186/1479-5868-4-6

[12] Taber DR, Chriqui JF, Powell LM, Chaloupka FJ. Association between state laws governing school meal nutrition content and student weight status: implications for new USDA school meal standards. JAMA Pediatr 2013; 167: 513-9. http://dx.doi.org/10.1001/jamapediatrics.2013.399

[13] USDA Office of Communications [homepage on the Internet]. News Release (Release No. 0023.12). USDA unveils historic improvements to meals served in America's schools: new standards will improve the health and wellbeing of 32 million kids nationwide, 2012[cited 2013 August 29]: Available from: http://www.usda.gov/wps/portal/usda/usdahome?contentid=2 012/01/0023.xml

[14] Cobb County School District [homepage on the Internet]. Title 1 school-wide plan for Brumby Elementary School, 2012 [Cited 2013 August 29]: Available from:http://www.cobbk12. org/brumby/Titlel/Title_I_plan_2012-13\%5B1\%5D.pdf

[15] Georgia Department of Education [homepage on the Internet]. Free and reduced price meal eligibility; October 31, 2010[Updated 2013 December 22; cited 2013 December 23]: Available from:http://app3.doe.k12.ga.us/ows-bin/owa/ fte_pack_frl001_public.display_proc

[16] Cullen KW, Watson KB, Dave JM. Middle-school students' school lunch consumption does not meet the new Institute of Medicine's National School Lunch Program Recommendations 201114: 1876-81.

[17] Scaglioni S, Salvioni M, Galimberti C. Influence of parental attitudes in the development of children eating behaviour. $\mathrm{Br}$ J Nutr 2008; 99(Suppl 1): S22-5.

http://dx.doi.org/10.1017/S0007114508892471

[18] WebMD [homepage on the Internet]. Healthy eating in children: Things that influence food choices [Updated 2011 August 29; cited 2013September 26]: Available from: http://www.webmd.com/a-to-z-guides/healthy-eating-inchildren-factors-that-influence-food-choices-topic

[19] Robert Wood Johnson Foundation [homepage on the Internet]. Does food and beverage marketing influence children's food choices? [Updated 2011 July 2011; cited 2013September 26]: Available from: http://www.rwjf.org/ content/dam/farm/reports/issue_briefs/2011/rwjf71703

[20] Adams MA, Pelletier RL, Zive MM, Sallis JF. Salad bars and fruit and vegetable consumption in elementary schools: a plate waste study. J Am Diet Assoc 2005; 105: 1789-92.

http://dx.doi.org/10.1016/j.jada.2005.08.013

[21] Caine-Bish N, Scheule B. Gender differences in food preferences of school-aged children and Adolescents. J Sch Health 2009; 79: 532-40. http://dx.doi.org/10.1111/j.1746-1561.2009.00445.x

[22] Cullen KW, Watson KB, Fithian AR. The impact of school socioeconomic status on student lunch consumption after implementation of the Texas public school nutrition policy. $J$ Sch Health 2009; 79: 525-31. http://dx.doi.org/10.1111/j.1746-1561.2009.00444.x

[23] CDC [homepage on the Internet]. Obesity among low-income preschool children, 2013 [Cited 2013 October 1]: Available from: http://www.cdc.gov/obesity/downloads/pednssfactsheet.pdf

[24] Nord M. Characteristics of low-income households with very low food security: An analysis of the USDA GPRA Food Security Indicator [monograph on the internet]. EIB-25. U.S. Dept. of Agriculture, Econ Res Serv 2007 [Cited 2013 October 11]: Available from: http://ageconsearch.umn.edu/ bitstream/6387/2/ei070025.pdf 
[25] Acs G, Nichols A. An assessment of the income and expenses of America's low-income families using survey data from the national survey of America's families [homepage on the Internet]. Washington, DC: The Urban Institute;Sept. 26, 2006 [Cited 2013 October 11]: Available from: http://www.urban.org/UploadedPDF/411382_surve.pdf

[26] Food Research and Action Center [homepage on the Internet]. Why low-income and food insecure people are vulnerable to overweight and obesity; 2010 [Cited December 3, 2013]: Available from: http://frac.org/initiatives/hunger-andobesity/why-are-low-income-and-food-insecure-peoplevulnerable-to-obesity
[27] Wharton C, Long M, Schwartz M. Changing nutrition standards in schools: The emerging impact on schoo revenue. J Sch Health 2008; 78: 245-51. http://dx.doi.org/10.1111/j.1746-1561.2008.00296.x

[28] USDA [homepage on the Internet]. Policy Memo Code SP 45-2013: Updated Offer versus Serve Guidelines for the National School Lunch Program and School Breakfast Program in School Year 2013-2014 [Updated 2013 June 13; cited 2013 August 29]: Available from: http://www.fns.usda. gov/cnd/governance/Policy-Memos/2013/SP45-2013os.pdf

[29] Anonymous. School food: Success stories. Child Obes 2012; 8: 404-8.

http://dx.doi.org/10.6000/1929-4247.2015.04.03.3

(C) 2015 Johnson et al.; Licensee Lifescience Global.

This is an open access article licensed under the terms of the Creative Commons Attribution Non-Commercial License (http://creativecommons.org/licenses/by-nc/3.0/) which permits unrestricted, non-commercial use, distribution and reproduction in any medium, provided the work is properly cited. 